\title{
PEMERANAN TOKOH NORA DALAM NASKAH RUMAH BONEKA KARYA TERJEMAHAN AMIR SUTAARGA (NASKAH ASLI $A$ DOLL'S HOUSE KARYA HENRIK IBSEN)
}

\author{
Supiriani Eka Lestari \\ Institut Seni Indonesia Yogyakarta, Indonesia
}

\begin{abstract}
Abstrak: Terjemahan naskah Rumah Boneka (A Doll's House) oleh Amir Sutaarga dari naskah asli $A$ Doll's House oleh Henrik ibsen adalah kritik egoisme kaum lelaki yang sedikit menyinggung isu kesetaraan gender terhadap kaum perempuan. Ibsen bertujuan untuk mengekspos stigma yang salah terhadap peran dan institusi sosial gender perempuan. Aktor utama dalam drama ini akan memerankan Nora dengan penerapan teori acting "magic if" yang dicetuskan oleh Constantin Stanislavski - dengan mengimajinasikan diri "as if" dan "if only" dimana aktor membayangkan dirinya berada di posisi Nora. Dalam pengaplikasian teori pemeranan ini, terjadi eksplorasi dalam berbagai tingkatan pada latihan untuk benar-benar menjiwai karakter Nora berikut dengan konflik-konflik yang dialaminya.
\end{abstract}

Kata Kunci: A Doll's House, Henrik Ibsen, Nora, Stanislavski, Magic If

\begin{abstract}
A translated script Rumah Boneka (A Doll's House) by Amir Sutaarga from the original script $A$ Doll's House by Henrik Ibsen which is a criticism onto human male's egoisms and slightly exposes the gender equality to human female. Ibsen aims to reveal the wrong social statements onto female's social role and its social institutions. The main actor in this play will portray Nora by applying the "magic if" acting theory which was introduced by Constantin Stanislavski - "as if" and "if only" kind of self-imagination where the actor imagines to be in Nora's shoes. In the application of this theory of acting, the exploration goes through certain levels of acting rehearsals to really get into the character of Nora's along with her conflicts.
\end{abstract}

Key word: A Doll's House, Henrik Ibsen, Nora, Stanislavski, Magic If.

\section{Pendahuluan}

Naskah A Doll's House Karya Henrik Ibsen ditulis pada tahun 1879 di Norwegia, dalam bahasa Norwegia berjudul $E t$ Dukkehjem dan diterjemahkan dalam bahasa Indonesia menjadi Rumah Boneka oleh Amir Sutaarga pada tahun 2007. Karya ini pertama kali dipentaskan di Royal Theater di Copenhagen, Denmark pada tanggal 21 Desember 1879. Naskah ini pernah dipentaskan di Indonesia pada tanggal 30 November sampai 04 Desember 2011 dan telah diadaptasi ke dalam konteks
Indonesia oleh Faiza Mardzoeki. Naskah Rumah Boneka berkisah tentang seorang istri yang berjuang melepaskan diri dari norma-norma sosial di Eropa kalangan menengah atas pada abad kesembilan belas.

Nora digambarkan sebagai istri ideal yang tinggal di rumah dan menjadi ibu rumah tangga yang baik namun Nora selalu dianggap seperti anak kecil yang lemah, pemboros, tidak mampu melakukan sesuatu yang berat, dan patut dikasihani oleh Torvald. Nora mempunyai satu rahasia besar dalam perkawinannya yang tidak 
diketahui Torvald selama delapan tahun pernikahan, Nora telah meminjam uang sebesar 250 pound dan menjadikan rahasia tersebut sebuah kebanggaan karena telah menyelamatkan nyawa Torvald. Nora tidak ingin memberi tahu Torvald karena akan membuat hubungan mereka menjadi tidak baik, mengingat Torvald memiliki pendapat yang kokoh sebagai laki-laki. Hal tersebut bisa membuatnya tersinggung dan merasa terhina. Nora berusaha untuk melunasi hutang dengan caranya sendiri, menyulam, bordir, menyalin tanpa sepengetahuan Torvald.

Melihat fenomena yang terjadi di masyarakat Era Victoria bahwa adanya kesenjangan antara laki-laki dan perempuan, laki-laki memegang peranan penting dalam tatanan sosial bermasyarakat dan perempuan dilihat lebih rendah dari suami mereka. Laki-laki lebih terdidik dan perempuan harus menghormati laki-laki karena mereka menyediakan kehidupan untuk perempuan. Hal ini tersirat di dalam naskah ketika Torvald memangil Nora dengan sebutan binatang peliharaan seperti "Apakah yang berkicau di luar burung murai kecilku itu?", atau ketika Torvald mencubit kuping Nora seperti anak kecil “" Nora! Kepala yang bodoh ini!“. Kalimat tersebut memperlihatkan bahwa Torvald memperlakukan Nora seperti anak kecil yang lemah dan harus dikasihani. Nora yang dianggap lemah dan tidak mampu berbuat apa-apa memperlihatkan dirinya di akhir cerita untuk memberontak dari norma-norma sosial yang telah diterapkan Torvald pada hubungan mereka. Nora meninggalkan Torvald setelah menyadari jika suaminya tidak benar-benar mencintai dirinya " kau tidak pernah mencintaiku. Kau cuma pikir sebagai sebuah kesenangan untuk mencintaiku". Nora menegaskan bahwa rumah mereka adalah ruang bermain, seperti saat ia bermain bersama boneka-bonekanya ketika masih kecil.
Tokoh Nora menjadi sangat menarik untuk diperankan karena memiliki karakter dengan psikologis yang kuat. Nora mengalami perlakuan sama oleh ayahnya yang kemudian berlanjut ketika Nora menikah dan diperlakukan sama oleh Torvald. Nora terlambat menyadari bahwa hal tersebut telah mengubur jati dirinya. Rasa simpatik Nora ketika ingin menyelamatkan nyawa Torvald dengan meminjam uang secara diam-diam dianggap sebagai sebuah kesalahan yang dapat menghancurkan reputasi keluarganya. Penulis melihat sisi kemanusiaan yang dimiliki Nora harus berbenturan pada sebuah tatanan sosial yang telah menyepakati bahwa perempuan tidak memiliki hak apapun dalam bisnis meskipun untuk menyelamatkan nyawa seseorang.

Pemeran ingin memerankan tokoh Nora karena belum pernah memerankan tokoh dengan karakter dan konflik seperti yang telah disebutkan. Pemeran merasa tertantang berperan sebagai Nora untuk mengasah kemampuan akting dalam bermain karakter. Tokoh Nora berusia 35 tahun dan memiliki tiga orang anak dari pernikahannya dengan Torvald Helmer. Dengan latar tempat di Norwegia serta tekanan psikis dan perubahan emosi yang dimiliki oleh tokoh Nora menjadi tantangan bagi pemeran. Selain itu pemeran juga dituntut untuk dapat menari Tarantella, menyanyi dan bermain piano hal ini belum pernah dilakukan oleh pemeran.

Naskah Rumah Boneka menjadi sangat menarik untuk dipentaskan sebagai ruang belajar bagi pemeran maupun pendukung yang terlibat. Isu-isu yang diangkat dirasa masih dekat dengan kehidupan masyarakat saat ini. Kesenjangan sosial dan gender menjadi konflik yang tidak ada habisnya untuk dibahas. Melalui naskah Rumah Boneka pemeran ingin menyampaikan bagaimana 
seharusnya kita memperlakukan orang lain dengan manusiawi tanpa melihat gender dan status sosial. Naskah ini bukan hanya menceritakan antara laki-laki maupun perempuan tetapi tentang manusia yang hidup sebagai satu.

Berdasarkan uraian latar belakang di atas, maka rumusan masalah adalah bagaimana memerankan karakter tokoh Nora dalam naskah Rumah Boneka Karya Henrik Ibsen dengan metode akting (Magic If) Stanislavski?

Melalui sebuah ide seorang pencipta ada tujuan mengapa karya tersebut harus lahir. Adapun tujuan dari proses pengkaryaan ini adalah untuk memerankan karakter tokoh Nora dalam naskah Rumah Boneka karya Henrik Ibsen dengan teori akting Stanislavski.

\section{Tinjauan Pustaka}

Hal pertama yang harus dilakukan aktor sebelum memainkan tokoh yang diinginkan adalah membaca dan membedah naskah agar aktor dapat mengetahui keseluruhan isi naskah. Karakter akan tergambar melalui dialog yang disampaikan tokoh atau dialog yang dilontarkan oleh lawan main tokoh maupun penjelas laku. Pemeran akan menganalisis naskah Rumah Boneka karya Henrik Ibsen menggunakan teori struktur dan tekstur teks drama George R. Kernodle. Kernodle merinci bahwa setidaknya ada enam sarana yang dapat menciptakan struktur dan tekstur dalam kegiatan menganalisis drama. Adapun enam nilai dramatik itu merupakan ide dari Aristoteles yang dianggap mampu menolong dalam menganalisis teks drama. Enam nilai dramatik yang dikemukakan oleh Aristoteles tersebut adalah plot, karakter, tema, dialog, musik ditafsirkan sebagai mood untuk drama modren, serta spectacle (Dewojati, 2012). Analisis naskah berpengaruh untuk menciptakan karakter "Nora" yang akan diperankan oleh aktor.

Seorang aktor panggung atau film, dia harus mampu memainkan karakterkarakter yang beragam macamnya, terkadang berbeda jauh dengan dirinya sehari-hari, dia harus mampu untuk "hidup" di "dunia" yang berbeda itu. Dia harus mampu menggunakan energi yang dimilikinya untuk meraih pengalamanpengalaman baru untuk dipersentasikan dalam sebuah pertunjukan (Sitorus, 2002). Pada sebuah pementasan biasanya kita menyaksikan para aktor sangat menghayati tokoh yang diperankan sehingga ketika di panggung tokoh itu benar-benar hidup.

Alat aktor adalah tubuh atau raga dan jiwa atau sukma-nya. Itulah yang harus terus menerus diasah dan dilatih agar siap dalam menghadapi menggali, dan memainkan peran. Oleh sebab itu, ada beberapa langkah dan tahapan yang harus diperhatikan (Riantiarno, 2011). Untuk mendalami tokoh Nora pemeran akan menggunakan teori yang telah dicetuskan oleh Stanislavski, magic if akan lebih menekankan pada pemeran untuk berakting mendalami tokoh Nora. Pemeran akan menggunakan imajinasinya untuk dapat menghayati peran dan memasuki pikiran tokoh. Stanislavski mengatakan bahwa tujuan seorang aktor adalah mempergunakan tekniknya itu menjadi aktualitas teater. Dalam hal ini imajinasi memainkan peran sangat penting sekali (Stanislavski, 2007). Pemeran akan menggunakan imajinasi "jika" seandainya aktor mengalami situasi yang dihadapi tokoh Nora. Situasi tersebut adalah semua yang ada pada naskah, fakta-fakta, kejadiankejadian, masa, dan kondisi kehidupan tokoh (Sitorus, 2002). Imajinasi tersebut dapat mendekatkan diri pemeran pada karakter yang akan diperankannya karena imajinasi yang kuat akan mengantarkan aktor pada akting yang meyakinkan pula. 
Setiap gerakan yang kau lakukan diatas panggung, bahwa setiap kata yang kau ucapkan adalah hasil kehidupan imaginasi yang tepat (Stanilavksy, 2007).

\section{Metode}

Metode merupakan cara teratur yang digunakan untuk melaksanakan pekerjaan agar tercapai sesuai dengan yang dikehendaki, atau cara kerja yang bersistem untuk memudahkan pelaksanaan suatu kegiatan guna mencapai tujuan yang ditentukan (KBBI, 2002). Setiap aktor mempunyai metode untuk menciptakan tokoh.

Akting adalah wujud yang kasat mata dari suatu seni peragaan tubuh, yang menirukan prilaku-prilaku manusia mencakup segala segi, lahir dan batin. Peniruan tersebut sebelumnya terlebih dahulu digagas, direka, dirancang, kemudian diselenggarakan di panggung untuk disaksikan penonton sebagai bentuk karya seni (Dewojati, 2012). Aktivitas fisik dapat dimasukan kedalam metode penciptaan sebelum aktor menjadi tokoh untuk meyakinkan penonton. Aktor haruslah kuat untuk bertahan di atas panggung, sehingga ditutut mempunyai fisik yang prima dan fleksibel.

Metode akan mempermudah pemeran dalam menentukan langkah-langkah untuk mencapai proses penciptaannya. Adapun metode yang dimaksud akan dijelaskan secara runtut.

\section{Analisis Naskah}

Setelah menemukan naskah yang diinginkan, aktor harus mendalami dan memahami naskah lakon. Analisis naskah dibutuhkan untuk mengetahui struktur naskah. Struktur merupakan element paling utama dan merupakan prinsip kesatuan lakuan (unity of action) dalam drama, yaitu tema, alur (plot) dan penokohan (Satoto, 2012). Pemeran harus membedah naskah agar mengetahui jalan cerita, peristiwa dan suasana disetiap pergantian adegan, spectacle yang akan dimunculkan. Setelah menganalisis naskah pemeran diharapkan dapat menganalisis karakter tokoh yang terdapat dalam naskah.

\section{Reading}

Reading membantu pemeran dalam memahami karakter tokoh lewat membaca dialog. Reading dilakukan sesuai dengan nada dan diksi yang tepat sesuai dengan bedah naskah sebelumnya, hal ini harus dilakukan agar tidak menciptakan kesalahpahaman. Pengucapan dialog yang buruk akan menimbulkan makna lain dan menyembunyikan maksud yang terdapat dalam naskah. Tahapan reading dilakukan berkali-kali hingga aktor hafal setiap dialog.

3. Latihan Dasar Keaktoran

Latihan dasar keaktoran seperti olah tubuh, olah vokal, olah rasa untuk melatih stamina, kelantangan suara, dan perasaan aktor sebelum memasuki latihan khusus untuk memerankan tokoh Nora. Latihan dasar ini akan terus dilakukan selama proses kreatif berlangsung sebagai memanasan agar tubuh pemeran dapat mudah menerima masukan dalam pencapaian keaktoran.

\section{Imajinasi}

Sebagai seorang aktor, sangatlah penting menggunakan dan melatih imajinasi di manapun berada. Idealnya, segala bentuk latihan fisik yang anda lakukan seharusnya menjadi latihan imajinasi, tidak hanya menggerakan tubuh (Oida, 2012). Aktor mengimajinasikan dirinya sebagai Tokoh Nora, dengan memasuki pikiran Tokoh. Bagaimana "jika" aktor mengalami situasi yang sama seperti yang dialami tokoh. Untuk melakukan magic if ada beberapa tahapan yang harus dilakukan.

a. Membuat Rancangan Tokoh Nora

Aktor harus membuat rancangan tokoh Nora yang akan diperankan, aktor harus mencari semua informasi tokoh Nora dengan membedah karakter yang ada dalam naskah Rumah Boneka agar lebih mudah 
untuk memerankannya. Aktor akan membuat halaman nol sebelum peristiwa dalam naskah ini berlangsung untuk mengetahui pola pikir tokoh dan tingkatan perasaannya. Pemeran akan membuat biografi tokoh melalui informasi yang telah di dapat agar dapat menciptakan tokoh Nora secara utuh.

b. Latihan Khusus

Latihan Khusus adalah latihan kebiasaan-kebiasaan tokoh yang tidak pernah dialami aktor sebelumnya. Aktor harus mempunyai latihan khusus untuk dapat memerankan tokoh Nora yaitu bermain piano dan menari tarantella. Belajar bermain piano ditempuh dengan cara menonton video di You tube kemudian mempraktekkannya langsung dan melakukan senam jari setiap hari agar jarijari lentur untuk memainkan piano. Belajar menari tarantella juga dilakukan untuk memenuhi kebutuhan tokoh. Tarian ini berasal dari negara Italia, penari akan mengunakan alat musik tamborin sebagai property, sehingga aktor juga harus mampu menari sekaligus memainkan tamborin. Latihan menari ini ditempuh dengan cara menonton video tarian tarantella di You Tube kemudian mempraktekannya ditemani seorang koreografer untuk melihat tempo hitungan serta mengawasi gerakan aktor saat latihan.

\section{c. Proses Latihan}

Proses berlatih adalah tahap seorang aktor melakukan apa yang telah dirancang untuk menciptakan tokoh. Pemeran akan berlatih vokal, gesture, dan rasa untuk untuk mempersiapkan tokoh menuju pentas. Latihan vokal dilakukan untuk mencari warna suara tokoh Nora seorang istri berusia 35 tahun, bangsa Norwegia, memiliki tiga orang anak. Vokal menjadi kunci utama bagi seorang aktor untuk menyampaikan pesan serta informasi mengenai karakter, suasana, usia, emosi, status sosial, dan sebagainya. Gesture harus dilatih secara detail agar dapat meyakinkan penonton, Tokoh Nora memiliki emosi berbeda kepada tokoh lain yang hadir yang berpengaruh pula pada gesture yang dilakukan tokoh sehingga aktor wajib untuk melatih dan mencari gesture yang sesuai dengan tokoh.

Olah rasa dilakukan agar pemeran dapat menghayati peran yang dimainkannya, Nora lebih cenderung menggunakan perasaannya dari pada pikirannya. Nora yang awalnya sangat mencintai Torvald dan rela melakukan apa pun untuk menyelamatkan nyawa Torvald, akhirnya memilih pergi setelah menyadari bahwa dia hanya sebuah boneka bagi Torvald. Melatih rasa aktor akan menepukan apa yang tokoh rasakan. Sukma yang baik akan mudah dimasuki setiap emosi tokoh.

d. Isolasi diri

Isolasi diri adalah latihan menganggap bahwa di dalam tubuh aktor terdapat manusia baru, aktor istirahat memainkan dirinya sendiri dan berusaha memainkan manusia baru yang ada dalam dirinya. Latihan seperti ini akan mempermudah seorang aktor untuk memerankan tokoh Nora. Pemeran harus mengenali dirinya terlebih dahulu kemudian menyimpan ingatan tersebut untuk beberapa waktu, dan pelan-pelan memasukan karakter tokoh tersebut kedalam pikiran, tubuh, dan rasa pemeran.

\section{Konsep Pemeranan}

Modal seorang aktor bukanlah wajah yang cantik atau potongannya yang tampan, tapi kesanggupanya untuk menghidupkan dan menjiwai suatu watak depan penonton. Penonton menyukainya bukan karena kepribadiannya, tapi justru karena ia berhasil meninggalkan kepribadiannya untuk menjadi pribadi yang lain. Seorang aktor akan sanggup memerankan tokoh yang berbeda-beda apabila menguasai teknik bermain peran yang baik, sehingga aktor dapat menyampaikan pesan dalam realita 
pertunjukan melalui tokoh yang diperankannya. Dalam memerankan tokoh Nora Helmer, pemeran akan menggunakan pendekatan akting realis. Pendekatan akting realis merupakan akting yang berusaha menyuguhkan tingkah laku manusia melalui aktor yang telah memahami karakter tokoh yang akan dimainkannya. Menciptakan pertunjukan sesuai kenyataan yang ada, seolah-olah penonton menyaksikan apa yang terjadi dalam kehidupan sehari-hari.

Pemeran akan memerankan tokoh Nora Helmer menggunakan teori akting realis Stanislavski yang berusaha menghadirkan tingkah laku secara wajar diatas panggung karena naskah Rumah Boneka karya Hendrik Ibsen ini membicarakan persoalan hidup yang terjadi dalam kehidupan sehari-hari. Pada naskah ini yang dibicarakan adalah kebebasan manusia, khususnya dalam hubungan rumah tangga suami dan istri yang tidak ada keterbukaan sehingga menimbulkan prilakuprilaku yang tidak baik, rasa cemas, takut, diremahkan, dan tidak adanya rasa percaya satu sama lain terjadi pada tokoh Nora. Teori akting Stanislavski sangat dibutuhkan untuk memerankan tokoh Nora karena dalam hal ini penciptaan dan pendandanan manusia baru didalam tubuh pemeran memerlukan pemahaman-pemahaman tentang fikiran dan cara hidup tokoh sebagai keberhasilan memerankan tokoh.

Proses penciptaan adalah salah satu tahapan seorang aktor dalam mempersiapkan diri unruk menciptakan karakter yang akan dipertunjukan kepada penonton. Bermain adalah suatu hasil dari proses yang panjang (Bolelavsky, 1960). Yang dimaksudkan adalah pertunjukan merupakan hasil yang telah didapatkan dalam proses yang dilalui. Adapun proses tersebut dilakukan pemeran dalam beberapa tahap.

\section{Proses Pemeranan}

Setiap aktor diharapkan memiliki kesiapan jasmani dan rohani yang sehat untuk dapat penciptakan dan memerankan tokoh. Alat utama sebagai seorang aktor adalah tubuh. Pemeran yang akan memerankan tokoh Nora dalam naskah Rumah Boneka harus mengerti betul bagaimana kondisi tokoh yang akan diciptakan. Kendala seorang aktor dalam proses pembentukan si aktor adalah diri si aktor sendiri. Kita harus menelaah ada apa dalam diri si aktor. Sama saja seperti yang ada dalam diri setiap orang lain yaitu raga dan sukma (Anirun, 1998). Dalam proses untuk memerankan tokoh Nora, pemeran menempuh beberapa tahap sebagai berikut.

1. Membaca untuk Memahami Naskah

Tugas pertama seorang aktor adalah membaca lakon (Anirun, 1998). Hal ini dilakukan sebagai sumber untuk mengetehui nilai-nilai apa yang terkandung didalam naskah dan peran seperti apa yang harus dimaninkan. Pada tahap ini setelah memilih naskah pemeran akan memperlajari naskah yang akan dipentaskan dalam sebuah pertunjukan teater. Pemeran membaca naskah bersama sutradara dan lawan main serta tim pendukung yang terlibat. Pada tahap ini pemeran dan lawan main akan mulai masuk kedalam peristiwa dan karakter masing-masing tokoh, juga bagaimana pengenalan emosi, nada dan tempo saat berbicara. Perlu diingat pada tahap proses awal pembacaan ini pemeran tidak boleh buru-buru menetapkan tensi, emosi dan nada bicara dari setiap dialog. Biarkan dialog yang diucapkan mengalir terlebih dahulu.

Membaca kalimat tidak hanya membaca kalimat perkalimat tetapi pemeran juga harus dapat membaca suasana, pikiran tokoh, konflik-konflik yang terjadi pada peristiwa, dan merumusakn bagaimana seorang tokoh tersebut dapat menyelesaikan masalah.

\section{Mencari Literasi}


Mencari literasi berguna untuk lebih memahami bagaimana realitas kehidupan masyarakat Norwegia pada tahun 1879 dan apa yang sedang terjadi pada tahun tersebut sehingga terciptanya naskah Rumah Boneka ini. Perlu dicari tahu informasi untuk memudahkan pemeran dalam memerankan tokoh Nora, agar gesture dan cara berdialognya bisa disesuaikan dengan tahun terciptanya naskah. Mencari informasi ini juga sangat berguna untuk para pendukung pertunjukan lainnya seperti penata kostum dan setting yang akan menghadirkan suasana Norwegia. Untuk mendapatkan informasi ini dilakukan dengan cara menonton film-film pada tahun tersebut dan blog yang ada di internet.

3. Berdiskusi

Setelah membaca naskah dan mencari literasi untuk memahami naskah. Tahap selanjutnya yang dilakukan adalah berdiskusi dengan pendukung pertunjukkan mengenai kemungkinan-kemungkinan yang terjadi pada naskah. Hal ini penting dilakukan karena untuk mementaskan sebuah naskah realis dibutuhkan informasi yang sedetail mungkin terkait dengan latar belakang tokoh, peristiwa, artistik, kostum, atau hal-hal lain yang mendasari naskah tersebut. Apabila terjadi perbedaan pendapat antara pendukung pertunjukan maka dapat didiskusikan dan disepakati bersama hingga akhirnya menjadi suatu pemahaman yang sama.

\section{Dramatic Reading}

Proses membaca naskah dengan dramatik membantu pemeran untuk lebih memahami karakter tokoh melalui dialog dan membantu mengambarkan suasana dramatik yang ada pada naskah Rumah Boneka. Melalui dramatic reading pemeran harus dapat memahami dialog lawan main, hal ini dilakukan agar pemeran dapat melakukan improvisasi apabila ada lawan main yang lupa dialog. Tahapan Reading ini dilakukan berkali-kali, dengan mengeksplorasi nada dan irama dialog sampai nememukan nada yang pas dengan emosi sebelum memasuki blocking sehingga pemeran dapat sekaligus menghapalkan dialog yang terdapat pada naskah.

5. Menghafalkan Naskah

Seorang aktor harus mampu menghafalkan seluruh isi naskah yang akan dipentaskan karena jika aktor tidak dapat menghafalkan dialog maka tidak akan ada informasi yang akan disampaikan pada penonton. Setiap aktor memiliki kapasitas daya ingat yang berbeda-beda. Pemeran yang akan memerankan tokoh Nora lemah dalam menghafal, sehingga memiliki cara sendiri untuk menghafalkan naskah. Pertama, memperbesar ukuran found pada naskah yang telah dicetak sehingga tulisan yang besar dianggap mampu membuat pemeran mengingat kalimat-kalimat dalam naskah. Kedua, merekam dialog-dialog yang panjang dan mendenganrkannya kembali mampu membuat pemeran mengingat dialog-dialog yang panjang. Meghafal dialog sambil bergerak juga mampu membantu daya ingat pemeran. Selain menghafal seorang aktor harus mengerti betul maksud dialog yang akan diucapkannya. Hal ini sangat bermanfaat untuk memahami motivasi kenapa kalimat atau dialog tersebut harus diucapkan.

6. Olah Tubuh

Sasaran olah tubuh adalah menciptakan tubuh yang lentur, adatif, dan pembongkaran terhadap bagian-bagian tubuh yang kaku (Anirun, 1998). Tubuh menjadi penting dalam tahapan proses untuk memerankan tokoh karena tubuhlah yang pertama kali akan dilihat oleh penonton, apakah tubuh aktor kokoh, lentur dan menjadi si karakter di atas panggung. Olah tubuh dilakukan sebagai pemanasan sebelum latihan berlangsung agar tubuh pemeran tidak lemas dan siap untuk menerima arahan-arahan sutradara. Latihan olah tubuh 
tersebut dilakukan oleh pemeran dangan beberapa cara berikut.

a. Latihan Stamina

Latihan dilakukan dengan cara mengelilingi lapangan secara berkala minimal 5 putaran. Selain lari mengelilingi lapangan, lari-lari kecil sambil menaiki tangga dilakukan sebanyak 5 putaran. Jalan jongkok mengelilingi lapangan sebanyak 1 putaran. Skot jump dan Sit Up minimal 50 kali dilakukan secara berkala setiap pagi setelah bangun tidur dan malam hari sebelum tidur. Plank dalam hitungan 50 kali dengan cara ambil posisi tengkurap di lantai dengan tangan sejajar di bawah bahu, angkat tubuh keatas hingga tubuh hanya bertumpu pada tangan jari-jari kaki. Selain latihan fisik seorang aktor juga harus menjaga ketahanan tubuhnya dengan cara mengatur pola makan dan tidur agar selalu sehat dan dapat menyelesaikan pencarian tokohnya.

\section{b. Latihan Kelenturan}

Latihan kelenturan dengan cara mengerakan bagian tubuh dari atas kepala hingga jari-jari kaki secara rutin setiap akan memulai latihan. Gerakan yang sering dilakukan dalam latihan kelenturan adalah menolehkan kepala ke kanan dan ke kiri, menganggukkan kepala ke atas dan ke bawah, menggelengkan kepala ke arah kanan dan kiri, masing-masing sebanyak 16 kali hitungan. Menggerakan bahu ke depan dan ke belakang, memutarkan pinggang ke kanan dan ke kiri dengan posisi kuda-kuda, meregangkan otot punggung dengan cara memutarkan tulang rusuk ke arah kanan dan kiri, meregangkan otot kaki mulai dari persendian paha, lutut dan pergelangan kaki dengan cara menekukkan kaki tarik keatas hingga lutut berada di dada dilakukan dikedua kaki. Setiap gerakan masing-masing dilakukan sebanyak 16 kali hitungan.

Latihan untuk meregangkan otot-otot tubuh lainnya dengan melakukan kayang hingga 50 hitungan, split hingga 50 hitungan. Mencium jempol kaki dengan cara duduk tegak, pertemukan kedua telapak kaki kemudian tubuh turun perlahan hingga mencium jempol kaki. Mengangkat kaki ke atas dengan cara berdiri tegak, tekukuk salah satu kaki ke atas kemudian letakan telapak tangan ke telapak kaki, luruskan kaki hingga ke atas menggunakan tangan.

c. Latihan Olah Rasa

Aktor harus memiliki sukma yang terlatih dengan baik agar gampang memasuki setiap emosi yang akan dimainkan. Seorang aktor wajib menghayati peranannya secara batin (Stanislavski, 2007). Olah rasa sangat diperlukan agar aktor dapat merasakan perasaan tokoh. Ada beberapa cara yang dilakukan oleh pemeran untuk melatih sukmanya, antara lain sebagai berikut.

\section{d. Imajinasi}

Imajinasi merupakan hal yang sangat bermanfaat untuk melatih daya khayal pemeran. Imajinasi yang baik akan membantu untuk menggambarkan suasana yang terjadi pada tokoh maupun peristiwa. Latihan yang dilakukan untuk melatih imajinasi adalah berada di satu ruangan, meletakan satu kursi ditengah-tengah ruangan tersebut dan membayangkan jika dikursi itu terdapat seseorang yang sedang duduk menunggu dan menatap. Latihan dimulai dengan menghadirkan emosi kemarahan terhadap bayangan yang sedang duduk tersebut kemudian memunculkan kesedihan dan kesenangan. Emosi marah, sedih, senang, dilakukan dalam beberapa tingkatan, jika dikatakan emosi marah berada pada level 1-10 maka pemeran harus menghadirkan tiga tingkatan emosi yaitu level 3, level 6, dan level 10. 
e. Konsentrasi

Latihan konsentrasi sangat penting karena akan mempengaruhi fokus pikiran dan emosi penonton pada sebuah pertunjukan. Stanislavski mengatakan bahwa seorang aktor harus punya pusat perhatian dan bahwa pusat perhatian itu seyogyanya tidak berada ditengah oditorium (2007). Apabila aktor tidak dapat berkonsentrasi itu akan mengganggu seorang aktor untuk bersikap biasa aja diatas panggung. Oleh sebab itu latihan memusatkan pikiran (konsentrasi) perlu dilakukan.

Untuk melatih konsentrasi dapat dilakukan dengan mengfokuskan mata dan pikiran pada satu titik. Pemeran harus fokus pada satu titik itu saja sambil mengingat kembali dialog dan peristiwa yang terjadi diatas panggung. Apabila pemeran tiba-tiba saja terhenti karena sesuatu hal, misalnya suara-suara ribut, atau teman yang sengaja memecahkan konsentrasi, bearti pemeran telah gagal melatihkanya.

\section{f. Relaksasi}

Relaksasi dilakukan oleh pemeran karena sering mengalami rasa tegang terhadap tokoh dan situasi ketika latihan. Cara ini dilakukan dengan duduk bersila, memejamkan mata dan menenangkan pikiran dalam waktu beberapa menit. Hal ini sering dilakukan pemeran pada malam hari sebelum tidur sambil mengingat kembali peristiwa adegan agar terekam dengan kuat didalam ingatan.

\section{g. Olah Vokal}

Melatih vokal sangat penting karena tidaklah mudah untuk mengeluarkan suara yang keras namun tidak berteriak, hal ini harus dipertimbangkan seorang aktor. Vokal aktor harus dapat didengar oleh penonton karena melalui vokal yang keras informasi yang dikeluarkan melalui dialog dapat didengar dengan jelas oleh penonton.
W.S Rendra dalam bukunya mengatakan bahwa suara (Vokal) adalah kendaraan imajinasi (2009). Vokal adalah kendaraan imajinasi yaitu karakter tokoh akan dirasakan melalui vokalnya. Untuk mewujudkan tokoh Nora yang sangat energik dibutuhkan latihan vokal agar artikulasi dan pernapasan pemeran tetap terjaga ketika maminkan tokoh Nora. Adapun latihan tersebut sebagai berikut.

\section{h. Latihan Pernapasan}

Latihan pernapasan dilakukan dengan cara menarik nafas dalam hitungan 1 sampai 8 masukan ke dalam perut dan keluarkan dengan perlahan. Efeknya ketika nafas ditarik perut akan mengembang, ketika nafas dikeluarkan perut akan mengempis. Latihan seperti ini dilakukan agar pemeran tidak mudah kehabisan nafas dan tidak merasakan lelah ketika diatas panggung karena pernafasaan yang tidak lancar akan mengakibatkan suara tersendat-sendat.

\section{i. Latihan Artikulasi}

Latihan artikulasi sangat penting bagi seorang aktor karena jarak proyeksi panggung ke penonton lumayan jauh sehingga dibutuhkan suara yang lantang dan jelas. Karena persoalannya bukan bagaimana mengucap kata, melainkan lebih pada bagaimana orang lain mendengar dan menyerapnya (Stanislavski, 2008). Artikulasi yang baik adalah ketika dialog dapat didengar dengan jelas oleh penonton. Latihan artikulasi dilakukan dengan cara membuka mulut semaksimal mungkin dengan membunyikan huruf vokal A-I-U-EO secara berkala. Mengucapkan dialogdialog panjang yang harus diucapkan dengan cepat secara berulang-ulang hingga dialog tersebut menubuh dan terdengar dengan jelas. 
j. Latihan Bernyanyi

Pada adegan awal Nora akan menyanyikan lagu Natal dengan perasaan senang. Pemeran yang tidak terbisa bernyanyi harus mempertimbangkan hal tersebut agar tidak menjadi aneh diatas panggung. Pemeran akan bernyanyi sambil memainkan alat musik. Pemeran melatih suaranya dengan menyanyikan lagu yang akan dibawakan pada adegan tersebut setiap hari dengan nada tinggi dan rendah. Hal ini dilakukan agar pemeran semakin terbiasa dan percaya diri untuk bernyanyi.

\section{Penerapan "The Magic If"}

Latihan ini berguna karena kreativitas tidak akan muncul jika realitas sesungguhnya ada. Lalu latihan "if" (jika) muncul, yaitu kebenaran yang dibayangkan di mana aktor harus mempercayai dengan lebih sungguh-sungguh dan dengan rasa antusias yang lebih besar untuk mengetahui kedalaman tokoh.

Pemeran harus berlatih menjalani kehidupan seperti tokoh Nora, sebagai contoh, dalam naskah Nora merasa bangga karena telah menyelamatkan nyawa suaminya meskipun harus berhutang dan menyicil hutang-hutang tersebut tanpa sepengetahuan suaminya. melalui satu contoh pemikiran dan perasaan tokoh yang didapatkan dari naskah tersebut pemeranharus berlatih creative if agar memiliki pemikiran serta perasa tersebut.

"setiap penemuan imajinasi seorang aktor harus dijabarkan seteliti mungkin dan harus ditegakkan dengan kukuh berdasarkan fakta-fakta harus sanggup menjawab menjawab semua pertanyaan (kapan, dimana, kenapa, bagaimana) yang ia ajukan sendiri tatkala ia mendorong kesanggupan-kesanggupannya untuk menemukan sesuatu yang baru guna membuat gambaran yang lebih jelas dari kehidupan pura-pura” (Stanislavski, 2007).
Pemeran harus lebih teliti membayangkan dan cara berfikir karakter tokoh Nora yang telah ditemukan dalam naskah. Membayangkan seolah-olah menjadi tokoh, saat membayangkan itulah letak imajinasi dan juga perasaan aktor yang jujur. Stanislavski mengatakan bahwa aktor harus merasakan apa yang mereka bayangkan menimbulkan permasalahan untuk menganjurkan mereka memiliki emosi yang harus sepadan dengan emosi tokoh yang mereka bayangkan (Mitter, 2002). Untuk menerapkan metode ini pemeran harus mengerti karakter Nora terlebih dahulu sehingga dapat mengimajinasikan dengan baik. Apabila pemeran tidak mengerti karakter tokoh proses imajinasi ini akan menjadi proses yang sia-sia karena kurangnya pengetahuan mengenai tokoh. Kendala dalam metode ini apabila seorang aktor tidak memiliki pembendaharaan perasaan dan suasana yang banyak untuk dapat menghadirkan imajinasi. Adapun langkah-langkah latihan yang dilakukan untuk menuju magic if adalah sebagai berikut.

\section{Membuat Rancangan Tokoh Nora}

Membuat rancangan tokoh Nora dilakukann agar pemeran mengetahui kebutuhan apa saja yang diperlukan untuk memerankan tokoh Nora sehingga pemeran mengetahui langkah-langkah apa saja yang harus dilakukan. Membuat rancangan tokoh Nora dengan cara membaca dan memahami naskah, menganalisis karakter tokoh Nora membuat halaman nol dan biografi tokoh melalui informasi yang ditemukan dalam naskah. Diketahui bahwa Nora belajar menari tarantella ketika ia berada di Capri, Italia dan pandai bernyanyi dan bermain alat musik piano. Informasi tersebut akan mempengaruhi bentuk tubuh dan cara berfikir tokoh. 
1. Latihan Khusus

Latihan khusus dilakukan untuk membiasakan pemeran dengan kebiasankebiasaan tokoh yang belum pernah dialami sebelumnya. Seperti bermain piano dan menari tarantella. Maka dari itu pemeran mencoba mendekatkan diri dengan kebiasaan-kebiasaan tokoh sebagai berikut.

Latihan menari tarantella, Nora akan menarikan tarian tarantella pada pesta topeng yang akan diadakan oleh keluarga Standbrog untuk merayakan Natal. Tarian tarantella ini diperlajari ketika Nora berada di Capri, Italia. Tarian ini memiliki gerakan yang energik serta harus memainkan tamborin sebagai properti tarian tersebut. Pemeran yang tidak terbisa menari dengan properti dan energik harus membiasakan diri agar mampu bermain dalam adegan tersebut. latihan ini dilakukan dengan menonton video bersama serorang koreografer yang akan mencari gerakan-gerakannya untuk selanjutnya dilatih secara rutin. Meskipun saat beraksi diatas panggung gerakangerakan tarantella tidak beraturan dan tidak mengikuti tempo, namun pemeran harus mempelajari gerakan tarian yang benar sehingga dapat dengan mudah merubahnya sesuai kebutuhan pemanggungan.

Latihan bermain piano, Belajar piano dilakukan aktor untuk menjadi tokoh Nora dengan cara melakukan pemanasan penjarian agar jari-jari tangan lentur dan dilakukan setiap minggu. Setelah dirasa sudah siap untuk belajar chord, pemeran menonton video turtorial bermain piano yang ada di you tube kemudian mempraktekannya. Setelah menemukan lagu yang akan dibawakan untuk pentas pemeran hanya melatihkan lagu tersebut agar benarbenar siap.

Dalam eksekusinya pemeran yang akan memainkan piano diatas panggung ditiadakan, musik akan diputarkan melalui rekaman, aktor hanya akan bergaya seolaholah sedang memainkan piano. Kendala yang dialami adalah karena pemeran yang mengikuti ujian tidak mampu menghadirkan piano sungguhan untuk dimainkan diatas panggung. Meskipun tidak dapat menghadirkan adegan dengan memainkan piano asli, pemeran tetap mendapatkan pelajaran melalui proses ini yaitu dapat memainkan piano dan mengerti nada yang mungkin dapat digunakan pada garapangarapan pertunjukan selanjutnya.

2. Latihan Pembiasaan Terhadap Tokoh

Tokoh Nora menggunakan sepatu hak dikarenakan pemeran memiliki ukuran tubuh lebih kecil dari pada lawan mainnya, sehingga harus menggunkan sepatu hak wanita untuk menyeimbangi lawan main. Untuk memakai sepatu hak wanita memang memerlukan latihan jika tidak terbiasa memakainya. Oleh karena itu pemeran mencoba untuk berlatih menggunakan sepatu hak jika berpergian ataupun latihan. pemeran juga harus membiasakan diri untuk menari tarantella dengan menggunkan sepatu hak. Pemeran menggunakan sepatu hak dengan tinggi $5 \mathrm{~cm}$.

Pada tahun 1879 wanita masih menggunakan pakaian dengan rok panjang dalam keseharian, dirumah maupun berpergian. Pemeran harus membiasakan diri untuk berjalan dengan rok panjang sehingga juga memungkinkan untuk pemeran menemukan cara berjalan tokoh. Pemeran menggunakan rok panjang ketika bepergian maupun latihan untuk membiasakan diri.

\section{Latihan Warna Suara}

Setiap manusia memiliki warna suara yang berbeda-beda, begitu pula dengan tokoh-tokoh yang akan dihadirkan dalam setiap pertunjukan pasti memiliki latar belakang dan warna suara yang berbeda. Diketahui Nora berusia 29 tahun, kekanakkanakan, dan memiliki tiga orang anak. Pemeran mencoba mencari warna suara tokoh Nora dengan cara mendengarkan dan memperhatikan setiap orang yang sedang 
berbicara. Kemudian pemeran mencoba untuk menirukan suara yang terdengar berat, suara yangs halus, dan suara cempreng yang menyakitkan telinga. Harapannya agar suara asli aktor tidak mendominasi suara tokoh. Pemeran harus dapat membedakan suaranya dari suara tokoh yang akan diperankan, sehingga benar-benar menjadi manusia yang baru.

4. Latihan Mimik Wajah

Latihan ini dilakukan agar pemeran dapat menemukan ekspresi wajah yang sesuai untuk merespon lawan main, suasana dan emosi serta garis-garis wajah tokoh. Latihan dilakukan dengan menonton film dan menirukan mimik wajah yang diperlihatkan oleh aktor yang ada di film tersebut. latihan lainnya dilakukan didepan cermin sambil berdialog. Hal tersebut dirasa mampu membantu pemeran untuk menemukan dan membiasakan garis dan mimik wajah tokoh yang akan diperankan.

Kendala dalam latihan ini adalah kurangnya waktu untuk menonton film dan menirukan, sehingga cara yang paling sering dilakukan adalah bercermin dengan membiasakan mimik wajah tokoh.

\section{Latihan Gesture (Matriks Tubuh)}

Naskah Rumah Boneka ini akan dipentaskan menurut tahun dan tempat terciptanya naskah, pemeran dituntut untuk dapat mengikuti tubuh orang Norwegia yang hidup pada tahun tersebut. Seperti ketegasan dan ketegapan postur tubuh sesuai karakter yang sudah ditemukan. Pemeran memulai latihannya dengan mencari informasi melalui beberapa film dan media lainnya, kemudian mengambil gerakan-gerakan yang sesuai untuk mengembangkannya kembali. Misalnya cara berjalan diambil dari tokoh Sabrina pada film Sabrina, gerak bahu dan tangan diambil dari tokoh Scarlett pada film One With The Wind kemudian dikembangkan kembali untuk menemukan gesture yang sesuai untuk tokoh Nora.
Setelah menemukan, gerakan-gerakan tersebut dibiasakan di waktu latihan maupun di luar latihan.

Pemeran yang tidak terbiasa rapi didepan meja makan pernah mencoba mengujikan karakter tokoh Nora ketika sedang makan disebuah angkringan dengan tubuh yang tegap dan table manner. Cara ini tidak berhasil karena pengunjung yang lainnya tiba-tiba melihat kearah pemeran, sehingga tidak dapat berkonsentrasi. Hal ini mungkin saja terjadi karena pemeran belum terbiasa dengan tokohnya dan belum mendalami perannya.

\section{Melatih Ingatan Emosi}

Dalam buku persiapan seorang aktor Stanislavski (2007) mengatakan bahwa :

"seperti halnya dengan ingatan visual, yang dapat menggambarkan kembali secara batiniah sesuatu yang sudah dilupakan, tempat atau orang, begitu juga emosi yang dapat menggembalikan perasaan yang kita rasakan. Mula-mura rasa itu mungkin tidak bisa diingat, tapi tiba-tiba sebuah kesan, sebuah pikiran sebuah benda yang kita kenal mengembalikannya debgan kekuatan penuh. Kadang -kadang emosi itu sama kuatnya dengan dulu, kadang-kadang agak kurang dan kadang-kadang perasaan yang sama dalamnya kembali, tetapi dalam bentuk yang agak berbeda"

Latihan ingatan emosi ini dilakukan pemeran untuk mengingat kembali emosiemosi yang pernah dialaminya di masa lalu. Ingatan-ingatan emosi tersebut akan sangat berguna untuk mengembangkan emosiemosi yang dialamai tokoh. Misalnya emosi dalam keadaan sedih ketika pemeran berpisah dengan keluarga untuk melanjutkan perkulihan dikembangkan kembali dengan emosi yang dialami tokoh ketika Nora sudah mulai pasrah dan akan meninggalkan rumah saat Trorvald akan membaca surat dari Krogstad. 
Latihan mengingat emosi juga dilakukan dengan cara mendengarkan musik-musik yang penuh dengan kenangan. Musik dapat membantu untuk mengingatkan kembali kenangan dan emosi-emosi terdahulu yang pernah dialami. Latihan ingatan emosi ini juga berguna bagi pemeran untuk mengingat kembali motivasi, blocking, emosi yang dilakukan saat latihan penggarapan adegan.

\section{Latihan Adaptasi Bersama Lawan Main}

Banyak aktor yang tidak mudah beradaptasi dengan lawan main yang baru ditemui dalam sebuah proses sehingga penting untuk mengadakan latihan sendiri diluar jadwal latihan rutin. Stanislavski mengatakan aktor harus belajar menyesuaikan pada keadaan, pada saat, pada pribadi-pribadi (Stanislavski, 2007). Adaptasi dan pendekatan yang dilakukan pemeran kepada lawan main dimulai dengan mengajak berdiskusi mengenai karakter tokoh, masa lalu tokoh, sehingga antar pemain bisa menemukan kemungkinankemungkian baru nada dialog, emosi, suasana dan motivasi gerakan. Membaca naskah bersama-sama diluar latihan juga membantu pemeran dan lawan main untuk saling menghafalkan dialog tokoh masingmasing. Selain itu latihan bersama lawan main diluar latihan juga dapat membangun chemistry antara sesama aktor.

Latihan bersama lawan main secara khusus ini tidak berjalan dengan lancar, banyak kendala yang dialami. Seperti tidak dapat menemukan jadwal yang pasti antara pemeran dan lawan main. Targetan hafalan yang tidak sesuai target membuat latihan tidak ada kemajuan. Susahnya membuang ego masing-masing aktor untuk ikhlas menerima dan memberi agar targetan yang telah disepakati bisa tercapai. Latihan ini tidak terlalu sering dilakukan, pemeran lebih sering bertemu dengan lawan main di proses latihan rutin.

\section{Menubuhkan Tokoh}

Setelah pemeran menemukan matriks tubuh, warna suara dan melakukan kebiasaan-kebiasaan tokoh. Pada tahap menubuhkan tokoh inilah letak imajinasi tokoh diujikan. Komponen-komponen untuk membentuk pemeran menjadi tokoh sudah ditentukan dan ditemukan. Pemeran akan mengimajinasikan dirinya sebagai tokoh Nora bukan hanya dalam bentuk fisik tetapi juga pikiran tokoh. Akting merupakan suatu pengungkit untuk membawa kita ke dunia luar yang aktual kedalam kebenaran imajinasi (Mitter, 2002). Tokoh Nora menyembunyikan sebuah rahasia dari suaminya Torvald, sehingga membuatnya menjadi manipulatif dan banyak sekali perubahan-perubahan emosi yang dialami tokoh Nora. Pemeran melatih perasaan Nora dengan cara menonton film yang suasana dan peristiwanya menyerupai apa yang dialami Nora dan mengimajinasikannya seandainya menjadi tokoh tersebut. Selanjutnya dalam kehidupan sehari-hari, apabila bertemu dengan lawan main aktor sering mengimajinasikan mereka sesuai tokoh-tokoh pada naskah.

Latihan lain untuk menubuhkan tokoh adalah mengisolasi diri. Mengisolasi diri pemeran untuk menjadi tokoh Nora. Pemeran berdandani tokoh secara fisik dengan menggunakan kostum, make-up, dan prilaku seperti tokoh. Sehingga pemeran bisa menjadi diri yang lain dan mendalami tokoh yang akan diperankannya. Pemeran melakukan magic if "jika" atau "seandainya" menjadi tokoh Nora Helmer ketika berada di atas panggung. Pemeran mempercayai dan merasa dirinya adalah Nora sebagai pencapaian pada saat pementasaan dilaksanakan.

\section{Simpulan}

Teater adalah sepenggal kehidupan yang diciptakan diatas panggung. Pada 
akting realis aktor harus mampu menghidupkan peran agar tercipta kesungguhan realita yang nyata. Menciptakan kenyataan dalam pertunjukan teater, tidak semata-mata karena ingin menirukan realita yang ada namun lebih sebagai keinginan untuk mewujudkan alam, untuk mengharapkan susunan realita yang tidak kita miliki dalam hidup. Hal tersebut tentu akan membentuk kepercayaan penonton dalam menonton kesungguhan aktor dalam memainkan peran dalam lakon.

Naskah realisme menggambarkan manusia biasa di dalam kehidupan sehariharinya, yang bertingkah laku dan berbicara dengan wajar (K.M, 2008). Begitupun dalam naskah Rumah Boneka karya Henrik Ibsen, masalah yang diungkapakan pada naskah tersebut adalah masalah yang sering terjadi dalam kehidupan sehari-hari. Nora dalam alam bahwa sadarnya mengalami tekanan yang dilakukan oleh orang-orang terdekatnya sendiri. Tekanan yang dialami Nora dimulai ketika suaminya mengalami sakit karena bekerja terlalu keras dan harus dibawa ke Italia untuk penyembuhannya. Namun pada saat itu mereka tidak memiliki cukup uang untuk pergi, dan Nora harus mencari cara untuk mendapatkan uang karena suaminya tidak mau jika harus meminjam pada Bank. Bertepatan dengan sakitnya Torvald, ayah Nora juga mengalami sakit keras sehingga Nora tidak sampai hati untuk meminta bantuan ayahnya demi kesembuhan Torvald. Sehingga Nora memutuskan untuk meminjam uang ke Bank dan memalsukan jaminannya, yaitu tanda tangan ayahnya. Pemasalahan inilah yang kemudian menjadi awal mula munculnya konflik dalam rumah tangga Nora. Surat hutang dengan tanda tangan palsu tersebut menjadi alat Krogstad untuk mengancam Nora untuk mau membujuk Torvald agar tetap mempertahankan kedudukan Krogstad di Bank.
Nora tidak ingin Torvald mengetahui bahwa ia telah meminjam dan memalsukan tanda tangan karena hal tersebut akan membuat hubungan mereka menjadi tidak baik. Sehingga Nora berusaha membujuk Torvald untuk tidak memecat Krogstad, namun karena sikap Nora ini Torvald menjadi semakin muak dan mengirimkan surat pemberhentian Krogstad. Hal tersebut membuat Nora semakin kacau karena setelah surat pemberhentian itu sampai ketangan Krogstad, maka surat hutang dan surat yang menceritakan tentang pemalsuan tanda tangan tersebut akan sampai ketangan Torvald. Nora mencari cara agar Torvald menunda membuka kotak suratnya dengan meminta untuk ditemai berlatih menari tarantella untuk acara pesta topeng.

Setelah pesta tersebut selesai Torvald membuka kotak surat dan membaca surat yang ditulis oleh Krogstad. Hal tersebut membuatnya marah dan mengatakan bahwa Nora adalah seorang istri yang tidak punya rasa terima kasih, tidak bermoral, tidak beragama, dan Torvald tidak mempercayai Nora untuk membesarkan anak-anak. Ketika surat balasan Krogstad yang kedua meminta damai dan tidak akan membesarkan masalah ini, Torvald sangat senang dan berubah tidak seperti sebelumnya, ia kembali menjadi seorang suami yang seolah-olah melindungi istrinya dan mengatakan bahwa telah memberikan maaf kepada Nora. Kejadian inilah yang kemudian membuat Nora berfikir bahwa mereka berdua tidak saling memahai satu sama lain, dan Nora memutuskan untuk pergi dari kehidupan Torvald untuk menjadi lebih baik dengan menjadi dirinya sendiri.

Penulis naskah, yaitu Henrik Ibsen ingin membongkar kebobrokan gagasangagasan masyarakat pada zamannya. Dalam naskah Rumah Boneka ini egoisme kaum laki-laki di hantamnya sambil sekaligus mengangkat kedudukan kaum perempuan. Seperti dalam naskah Torvald 
memperlakukan Nora layaknya boneka, menjadikannya mainan dan hiasan dalam rumah yang harus menuruti segala keinginan Torvald. Demi nama baik keluarga, kebebasan dan kebebasan manusia boleh saja dikorbankan. Hal tersebut terjadi dalam peristiwa yang ada di naskah kedudukan wanita dalam satu pihak dimanjakan, dipihak yang lain tidak dihargai sebagai seorang manusia (dewasa). Nora pada akhir naskah ini digabarkan sebagai perempuan yang memiliki pandangan berbeda dari tokoh-tokoh yang lain. Nora seperti arti namanya membawa cahaya terang untuk mendapatkan perubahan dalam hidupnya, yaitu menjadi dirinya sendiri.

Ketertarikan aktor pada naskah Henrik Ibsen kemudian mewujudkannya dalam bentuk pementasan teater. Dalam pementasan ini aktor ingin beraksi secara wajar dengan membawakan naskah yang memiliki konflik yang sering terjadi dalam kehidupan sosial sehari-hari. Menurut seniman realisme, sesuatu harus dilihat atau dilukiskan menurut keadaan yang sebenarnya. Dengan demikian mereka mengamati sesuatu dengan kacamata yang objektif, tidak boleh dengan sengaja diindah-indahkan atau tidak boleh pula dibuat lebih buruk (Anwar, 2005). Banyak sekali aktor yang beraksi diatas panggung hanya sekedar untuk dilihat indah di mata penonton tetapi tidak memperhatikan kedalaman karakter pada tokoh yang dimainkannya. Sehingga aktor yang seperti itu tidak dapat menghidupkan tokohnya.

Untuk memerankan tokoh Nora, pemeran menggunakan teori akting Stanislavski Magic if dengan mengimajinasikan "jika" atau "seandainya" pemeran adalah tokoh Nora dengan melakukan metode-metode latihan menuju magic if sehingga pada saat pementasan pemeran benar-benar menjadi tokoh. Mengamalkan akting realis, yaitu akting yang berusaha menyuguhkan tingkah laku manusia melalui diri aktor dari hasil mengerti karakter yang akan dimainkannya. Apa yang terlihat diatas panggunng harus seperti "kenyataan" yang ada. Menciptakan ilusi diatas panggung, seolah-olah penonton menyaksikan apa yang terjadi dalam kehiduapan sehari-hari. Namun tetap harus diingat, meskipun "seolah-olah nyata" pemeran harus menyadari bahwa aksinya akan ditonton oleh banyak orang. Pemeran harus menguasai materi-materi keaktoran agar penonton dapat menikmati pertunjukannya.

Pemeran yang akan memerankan tokoh harus melalui persiapan-persiapan keaktoran untuk menciptakan karakter yang akan dikemas dalam sebuah pertunjukan. Untuk melalui setiap proses tersebut tidak sepenuhnya berhasil banyak sekali kendala yang dihadapi pemeran dari segi metode yang tidak berhasil dilakukan, gaya arahan sutradara, lawan main yang tidak begitu menguasai peristiwa, hingga aspek-aspek pertunjukan lain yang membuat pemeran tidak fokus dalam proses untuk memerankan tokohnya. Namun hal tersebut akhirnya dapat dilalui dengan penuh kesabaran dan ikhlas menerima segala kondisi yang terjadi selama proses. Menumbuhkan rasa percaya antara sesama pemain, pemeran dan sutradara, pemeran dan tim pendukung pertunjukan lainnya membuat aktor semakin tenang untuk menjalankan tugasnya.

\section{Daftar Pustaka}

Anirun, Suyatna. (1998). Menjadi Aktor. Bandung: PT. Reka Media Multi Prakarsa.

Anwar, Chairul. (2005). Drama Bentuk Gaya dan aliran, Yogyakarta: Elkaphi.

Bolelavsky, Richard. (1960). Enam Pembelajaran Pertama bagi Calon Aktor (Terjemahan Asrul Sani), Jakarta : Usaha Penerbit Djaja Sakti. 
Dewojati, Cahyaningrum. (2012). Drama Sejarah, Teori, dan Penerapannya. Yogyakarta : Javakarsa Media.

KM, Saini. 2008. Dramawan dan Karyanya. 2008. Bandung : Angkasa.

Mitter, Shomit. (2002). Sistem Pelatihan Stanislavski, Brecht, Grotowski dan Brook. Yogyakarta : Arti.

Oida, Yoshi dan Marshall, Lorna. (2012). Ruang tubuh aktor. (terjemahan Arief Mardiono). Surabaya : Dewan Kesenian Jawa Timur.

Rendra, W.S. (2009). Seni Drama Untuk Remaja. Jakarta : Burung Merak Press.

Riantiarno, Nano. (2011). Kitab Teater 'Tanya Jawab Seputar Seni Pertunjukan'. Jakarta: PT. Gramedia Widiasarana Indonesia.

Satoto, Soediro. (2012). Analisis Drama dalam Teater bagian 1. Yogyakarta: Penerbit Ombak.

Stanislavski, Constantin. (2007). Persiapan Seorang Aktor terjemahan Asrul Sani. Jakarta: Pustaka Jaya.

Stanislavski, Constantin. (2008). Membangun Tokoh. Jakarta : KPG (Kepustakaan Populer Gramedia).

Sitorus, Eka D. (2002). The Art Of Acting (Seni Peran untuk Teater, Film dan TV), Jakarta: PT. Gramedia Pustaka.

Tim Penyusun Kamus Pusat Bahasa, (2002). Kamus Besar bahasa Indonesia. Jakarta: Balai Pustaka. 